\title{
Rediscovery of Prostanthera staurophylla F.Muell. and reinstatement of $P$. teretifolia Maiden \& Betche (Lamiaceae)
}

\author{
John T. Hunter ${ }^{1}$, John B. Williams $\dagger^{2}$ and Barry J. Conn ${ }^{3}$
}

\author{
${ }^{1}$ School of Human \& Environmental Studies, The University of New England, \\ Armidale NSW 2351, Australia \\ ${ }^{2}$ Botany, Centre for Ecology, Evolution and Systematics, The University of New England, \\ Armidale NSW 2351, Australia \\ ${ }^{3}$ National Herbarium of New South Wales, Royal Botanic Gardens and Domain Trust, \\ Mrs Macquaries Road, Sydney NSW 2000, Australia
}

\begin{abstract}
A population of Prostanthera staurophylla was recently rediscovered in the Mt Mackenzie area near Tenterfield on the Northern Tablelands of New South Wales. A detailed morphological comparison of these plants with the previously known population occurring in the Torrington area revealed that the populations were morphologically sufficiently distinct from each other to be recognised as separate species. Prostanthera teretifolia is reinstated as a distinct species, separate from P. staurophylla. The former species occurs near Torrington, whereas, P. staurophylla is restricted to the Mt Mackenzie area near Tenterfield. Descriptions, botanical illustrations and comments on the conservation status of each species are provided.
\end{abstract}

\section{Introduction}

The staff of the Northern Tablelands Region of the New South Wales National Parks and Wildlife Service (Department of Environment and Conservation) have been conducting floristic and vegetation inventories of the reserves within their care since 1997. These surveys have resulted in extensions of ranges for a number of highly restricted species and the discovery of many new taxa (Hunter et al. 1996; Hunter 1997; Hunter 1998; Hunter \& Copeland 2001). During a flora survey of Mt Mackenzie Nature Reserve (by one of us - JTH), specimens were collected of a Prostanthera growing amongst heath plants within crevices of a single granite outcrop. Although this plant was tentatively identified as Prostanthera staurophylla (sensu lato - as circumscribed by Conn 1992), an initial comparison of the morphological features of these plants, with those that occur in the Torrington area, suggested that they were distinct.

$†$ Deceased 31 July 2005 
The plant collector Charles Stuart originally made collections of Prostanthera staurophylla from the Tenterfield area (Northern Tablelands region, NSW) while he was a gardener on a property in that region (Orchard 1999). These collections were sent to Ferdinand von Mueller who described the taxon in Fragmenta Phytographiae Australiae (Mueller 1875). However, since Stuart made these original collections, definitive material conspecific with the type has not been recollected. In 1908, based on collections by Richard Cambage in the Torrington area, Prostanthera teretifolia was described (Maiden \& Betche 1908). Using the herbarium collections available and limited field knowledge, Conn (1992) incorrectly assumed that P. staurophylla represented a precociously flowering juvenile growth stage of $P$. teretifolia since the juvenile leaves of this latter species are superficially similar to the adult leaves of $P$. staurophylla. Thus, the two taxa were considered synonymous and combined under $P$. staurophylla, which had nomenclatural precedence (Conn 1992). However, the rediscovery of populations conforming to the type material of Prostanthera staurophylla sens. str. has clarified the distinctions between these two taxa and provided evidence that Prostanthera teretifolia (sensu stricto), occurring near Torrington, should not have been reduced to the synonymy of P. staurophylla.

\section{Terminology}

The terminology used in this paper follows Conn (1984), with modifications to inflorescence terminology defined in Conn (1995).

\section{Key to species}

An excerpt from the Key to species of Prostanthera (Conn 1992, p. 647, couplet 27 ) is amended to incorporate the reinstatement of $P$. teretifolia as distinct from P. staurophylla.

27 Branches densely covered with short curled hairs; bracteoles not persistent

27a Adult leaves grey-green, strongly revolute such that lamina appears subterete, 5-16 mm long; margin entire or deeply 2- or 3-fid, densely covered with sessile glands; branches densely covered with sessile glands; anther appendage absent or minute

P. teretifolia

$27 \mathrm{a}^{*}$ Adult leaves lime- to dark green, oblong or linear, if lobed, then lobes linear, never terete-like, 2-9 mm long, deeply (2-)3(-7)-fid, with scattered glandular hairs adaxially; branches densely covered with podiate glandular hairs; anther appendage present P. staurophylla

$27^{\star}$ Branches glabrous between nodes or sparsely to densely covered with \pm straight, spreading to appressed hairs; bracteoles persistent [to couplet 28] 


\section{Taxonomy}

Prostanthera staurophylla F.Muell., Fragmenta Phytographiae Australiae 9: 73 \& 74 (1875).

Lectotype (here designated): New South Wales: Northern Tablelands: '12 miles SW of Tenterfield', C. Stuart (MEL 43669); probable isolectotypes: 'New England', C. St. (K); 'Nova Anglia,' 'Prostanthera trilobata Fv M ined.', C. St., 1869 (K); 'New England', C. Stuart (NSW 134503) (refer 'Typification', below).

Erect to spreading shrub 1-1.8 m high. Branches \pm terete to sub-quadrangular, densely glandular-pubescent with sub-sessile glands, tubercular hairs throughout, nonglandular hairs multicellular, curled or crisped, 0.5-1.2 mm long, white. Leaves limeto dark green, strongly aromatic (when crushed); petiole distinct, 0.6-1.2 mm long; lamina elliptic to oblong or more commonly widely trullate or cross-shaped, deeply (1-) 3 (-7)-lobed, 2-9 mm long, 0.9-7 $\mathrm{mm}$ wide, discolorous, abaxial surface paler and densely covered with curled or crisped non-glandular hairs, particularly along mid-vein and lateral veins towards lobes where distinct and raised, margin recurved but never revolute; adaxial surface sparsely glandular when young, less dense towards petiole, sparsely scabrous particularly on margins and apices, mid-vein depressed. Flowers axillary, solitary. Podium $0.7-1.5 \mathrm{~mm}$ long, sparsely hairy and glandular. Prophylls persistent, inserted below the calyx base (propodium to anthopodium ratio $3-4)$, elliptic to narrowly ovate, $0.3-0.4 \mathrm{~mm}$ long, $0.15-0.25 \mathrm{~mm}$ wide, glandular. Calyx 3-4 mm long, lime-green, sometimes with a purple-maroon tinge; outer surface sparsely glandular; inner surface glabrous; margin fimbriate with multicellular white hairs $0.2-0.3 \mathrm{~mm}$ long; abaxial lobe broadly ovate, $1.5-2.5 \mathrm{~mm}$ long, 2-2.5 mm wide, apex rounded; adaxial lobe broadly ovate, $1.2-1.6 \mathrm{~mm}$ long, apex obtuse to rounded. Corolla 15-18 mm long, bluish mauve with darker markings; outer surface glabrous; inner surface sparsely hairy; tube 8-10 mm long; abaxial median lobes transversely broad-spathulate, 5-6 mm long, 6-7 $\mathrm{mm}$ wide, apex irregular, rounded and bilobed; lateral lobes elliptic, 3-4 mm long, 3-4 mm wide, apex rounded; adaxial median lobepair very depressed ovate, 1-2 mm long, 9-10 mm wide. Stamens inserted 3-5 mm above base of corolla; filaments 3-6 mm long; anthers $0.8-1.4 \mathrm{~mm}$ long, connective extended to form a basal appendage 1-1.4 mm long, terminating in narrowly triangular trichomes. Pistil 7.5-9 mm long (Fig. 1).

Selected specimens: New South Wales: Northern Tablelands: Mt Mackenzie Nature Reserve, SW of Tenterfield, J.T. Hunter 14377-80, 12 Mar 2001 (all NSW); loc. cit. J.T. Hunter s.n., 01 Nov 2004 (NSW, spirit); loc. cit. J.B. Williams, 29 Sep 2004 (NE, NSW).

Notes: the discovery of the Mt Mackenzie population of $P$. staurophylla is the first record of this species (sensu stricto) for 130 years. The affinities of Prostanthera staurophylla are unclear; however it is expected that it will prove to be closely related to $P$. teretifolia from the Torrington area. This species differs from $P$. teretifolia by its adult leaves being 3-7-lobed, not terete; the lime- to dark green coloured leaves as opposed to grey-green; the presence of a distinct anther appendage (lacking or minute in $P$. teretifolia); and the habit which is taller in mature specimens and usually develops into an erect, sometimes leafless, single stem ( $P$. teretifolia is an erect to spreading, multibranched from base, leafy shrub). Since the leaves of P. staurophylla are not terete, the distinctly glandular abaxial leaf surface of this species is visible (abaxial leaf surface not visible in $P$. teretifolia). The flowers of $P$. staurophylla have distinct markings on the inner surface of the corolla, whereas these markings are absent in P. teretifolia. These and other useful distinguishing features are summarised in Table 1. 

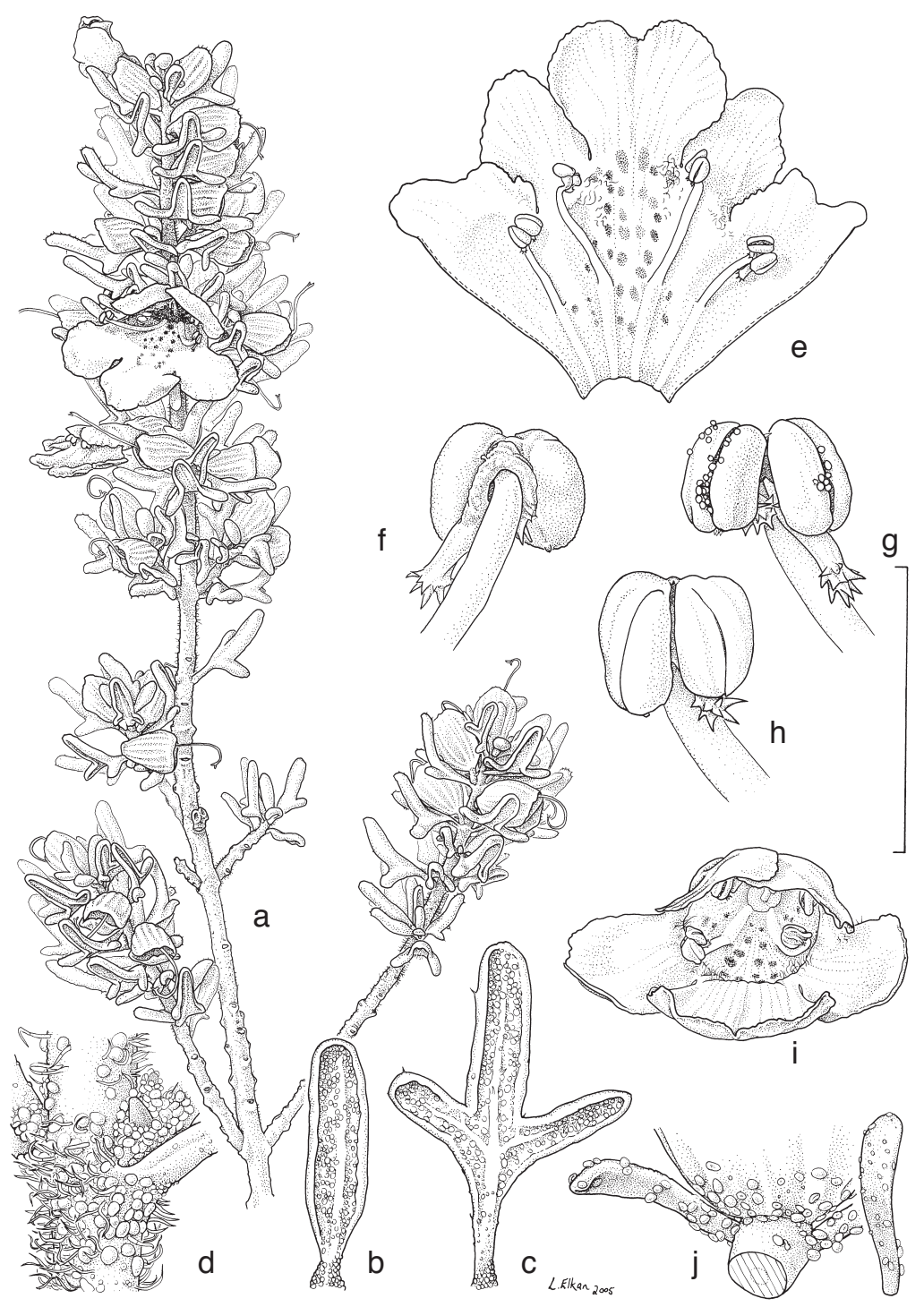

Fig. 1. Prostanthera staurophylla F.Muell. a, branchlet; b, entire leaf (abaxial surface); c, 3-lobed leaf (abaxial surface); d, detail of nodal area of branchlet and base of leaves; e, open flower showing corolla and stamens; f, adaxial (upper) stamen, showing dorsal surface of anther, connective and appendage; $\mathbf{g}$, adaxial stamen showing ventral surface of anther, and connective appendage extending from behind; $\mathbf{h}$, abaxial (lower) stamen showing dorsal surface of anther, connective and appendage; $\mathbf{i}$, flower showing dots on corolla tube and stamens (ventral view); j, base of calyx, showing prophylls, with one prophyll detached (from J.T. Hunter s.n., 1 Nov 2004, NSW). Scale bar: $a=20 \mathrm{~mm}, \mathrm{~b} \& \mathrm{c}=6 \mathrm{~mm}, \mathrm{~d}, \mathrm{f}, \mathrm{g}, \mathrm{h} \& \mathrm{j}=2.4 \mathrm{~mm}$, e \& $\mathrm{i}=10 \mathrm{~mm}$. Illustration by Lesley Elkan. 
Etymology: in reference to the cross-shaped leaves, referring to the divided nature of the leaves which in some cases resemble a cross.

Typification: the protologue of this species states 'In rupibus graniticis Novae Angliae inter vicum Tenterfield et flumen Severn; C. St.' (Mueller 1875, p. 73). The label on the single collection of P. staurophylla held at MEL (MEL 43669) also refers to 'Granite rocks' and summarises the locality as ' 12 Miles SW of Tenterfield'. Together with the morphological similarities of these collections to the protologue, this collection is here selected as the lectotype. The MEL collection does not provide the name of the collector(s); however, the label is thought to be handwritten by Charles Stuart, with identification 'Prostanthera staurophylla F.M.' (at the bottom of the label) added at some later time by Ferdinand von Mueller.

The two collections of P. staurophylla by Charles Stuart, held at K (as listed above), are here regarded as probable isolectotypes. Both of these collections refer to the collection locality as 'New England' or 'Nova Anglia'. The protologue refers to the locality in the Latin form 'Novae Angliae'. Both of these collections use the abbreviation 'C. St.' for the collector Charles Stuart. This abbreviation is also used in the protologue. The single collection of this species by Charles Stuart from 'New England', on 'Phytologic Museum of Melbourne' label (handwritten at some later date by Ernst Betche) (NSW 134503) is also regarded as a probable syntype. A note added by Nerida Ford (ex NSW; in her own hand) to this latter collection suggests that it is 'possibly a para-type'. However, since Mueller did not specifically designate a holotype, this collection should more correctly be regarded as a probable syntype (according to Article 9.5, Greuter et al. 2000). She also added that the 'Type locality was New England, from the vicinity of Tenterfield to the Severn River' but this information is merely a reference to the Protologue (Mueller 1875). All three collections morphologically correspond with the description provided in the protologue. The NSW collection and the two specimens held at K are here regarded as probable isolectotypes.

Distribution: scattered plants within a single diffuse population of Prostanthera staurophylla were found at Mt Mackenzie Nature Reserve, Northern Tablelands, New South Wales (Fig. 3).

Habitat: Prostanthera staurophylla grows in open and exposed situations within crevices of a granitic outcrop at an elevation of $1200 \mathrm{~m}$ above sea level. This species is a co-dominant with Kunzea opposita F.Muell. and Leptospermum novae-angliae Joy Thomps., with an understorey dominated by Leucopogon neoanglicus F.Muell. ex Benth., Lomandra longifolia Labill., Lomandra filiformis (Thunb.) Britten, Gahnia aspera (R.Br.) Spreng., Themeda triandra Forssk. and Brachyscome stuartii Benth.

Conservation status: Prostanthera staurophylla has a very restricted occurrence being only known from the Mt Mackenzie Nature Reserve. The population size is estimated to be less than 500 individuals, occurring in an area of about 200 metres long and 80 metres wide. Although fire is unlikely to have occurred in this area for over 30 years; many seedlings were noted underneath mature stands. This suggests that germination is occurring naturally without the stimulus of fire, which is typical of plants endemic to granitic outcrops (Hunter 2003). This species should be considered as endangered and warrants listing as threatened in the schedules of the New South Wales Threatened Species Conservation Act 1995 (TSC 1995, TSC 2002, TSC 2004), the Environment Protection and Biodiversity Conservation Act 1999 (EPBC 1999), and as Critically Endangered $(\mathrm{CR} B 1 \mathrm{a}+\mathrm{B} 2 \mathrm{a})$ in the IUCN Red List of Theatened Species (Baillie et al. 2004). 


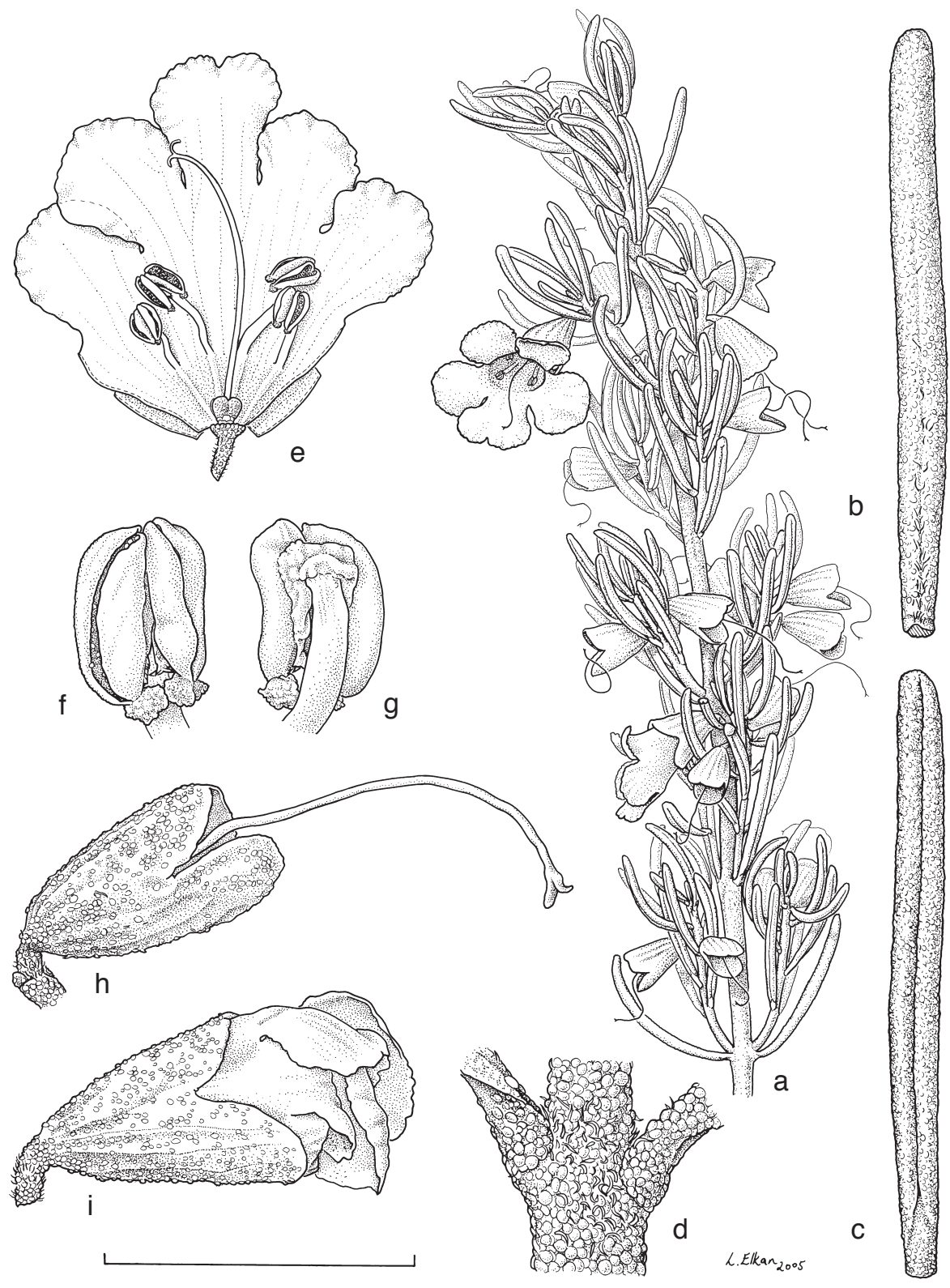

Fig. 2. Prostanthera teretifolia Maiden \& Betche a, branchlet; b, leaf showing adaxial surface; c, leaf showing abaxial surface; $\mathbf{d}$, detail of nodal area of branchlet and base of leaves; e, open flower showing corolla, stamens and gyneocium; f, stamen, showing ventral surface of anthers, locular appendages and minute connective appendage (visible between locules of anther); $g$, stamen showing dorsal surface of anthers, locular appendages and connective; $\mathbf{h}$, fruiting calyx and persistent style and stigma (lateral view); i, flower bud (lateral view) (from Cambage s.n., 29 Sep 1907, NSW 134430). Scale bar: a=20 mm, b, c, h \& i=6 mm, d, f \& g=2.4 mm, e=10 mm. Illustration by Lesley Elkan. 
Prostanthera teretifolia Maiden \& Betche, Proc. Linn. Soc. New South Wales 33: 313 \& 314 (1908).

Holotype: New South Wales: Northern Tablelands: Torrington, R.H. Cambage s.n., 29 Sep 1907 (NSW 134430).

Erect to spreading shrub $0.3-1 \mathrm{~m}$ high, multi-branched from near base; branches quadrangular, tending to become sub-terete, very densely glandular with sub-sessile, semi-hemispherical glands, densely with multicellular curled (eglandular) hairs (hairs 0.1-0.3 mm long) (refer details in 'Notes' below). Leaves grey-green, strongly aromatic (when crushed); petiole distinct or indistinct, 0.6-1.8 mm long; lamina dimorphic; juvenile lamina, rarely present, entire to deeply 3-lobed, 5-10 mm long, 1-9 mm wide. Adult lamina linear, subterete (refer details in 'Notes' below), entire or 2- or 3-lobed, 5-16 mm long; 0.5-0.9 mm wide, abaxial and adaxial surfaces densely glandular with sub-sessile, semi-hemispherical glands and with occasional crisped hairs (particularly on younger leaves). Inflorescence racemiform on leafy branches; uniflorescence monadic with flowers occurring singly in the axils of leaves. Podium 0.6-0.9 mm long, densely hairy and glandular. Prophylls not seen, soon deciduous, inserted near midpoint of podium (propodium to anthopodium ratio c. 1.3). Calyx 4-5 mm long, green, adaxial surface often purplish and/or with a purple-maroon tinge; outer surface densely glandular with sub-sessile, semi-hemispherical glands, sometimes with a few scattered hairs; inner surface glabrous; lobes depressed-ovate; abaxial lobe 1.5-2 mm long, apex obtuse to rounded; adaxial lobe 1-1.2 mm long (shorter than abaxial lobe), apex almost truncate. Corolla 8-9 mm long, bluish purple, violet or white; outer and inner surface glabrous; tube 4.5-5 mm long; abaxial median lobes broadly spathulate, c. $4 \mathrm{~mm}$ long, 4-4.4 mm wide, apex slightly irregular, rounded, shortly bilobed; lateral lobes elliptic, 3-4 mm long, 3-4 mm wide, apex rounded; adaxial median lobe-pair very depressed ovate, $2.2-3 \mathrm{~mm}$ long, $6.5-8 \mathrm{~mm}$ wide. Stamens inserted $2.2-2.5 \mathrm{~mm}$ above base of corolla; filaments $1.2-2.5 \mathrm{~mm}$ long; anthers $0.8-1.3 \mathrm{~mm}$ long, with base of lobes extended to form a locular appendage $0.2-0.3 \mathrm{~mm}$ long; connective extending to form an indistinct, minute appendage (up to $0.2 \mathrm{~mm}$ long) or appendage absent. Pistil c. $6 \mathrm{~mm}$ long (Fig. 2).

Selected specimens: New South Wales: Northern Tablelands: Torrington, J.L. Boorman s.n., Jan 1911 (BM, K, NSW); J.B. Williams s.n., 20 Nov 1965 (NSW); J.B. Williams s.n., 29 September 2004 (NE, NSW); c. $1 \mathrm{~km}$ N of Torrington township, A.J. Whalen $109 \&$ R.G. Coveny, 18 Oct 1993 (BRI, MEL, NSW); 4 miles NW of Torrington, H. Wissman s.n., Apr 1967 (NSW). North Western Slopes: Eastern Binghi, N of Torrington, J. Benson s.n., 3 Aug 1991 (NSW).

Etymology: in reference to the 'terete' (subterete) and linear foliage. The vernacular name for this species has been once recorded as 'Turpentine bush' (J.B. Williams s.n., NSW 134377).

Typification: the protologue (Maiden \& Betche 1908) cites the habitat as 'in glabris saxosis graniticis'. This is in agreement with the notes (in Cambage's hand) on the holotype (lower left of herbarium sheet) that describes the plant as growing 'On bare acid granite rocks'. The handwritten label (lower right) cites the locality as 'Torrington $\mathrm{n}[\mathrm{ea}] \mathrm{r}$ Deepwater'; however, this additional information is not supported by the protologue.

Distribution: found commonly on rocky granite outcrops within the Torrington area of New South Wales (Fig. 3). 


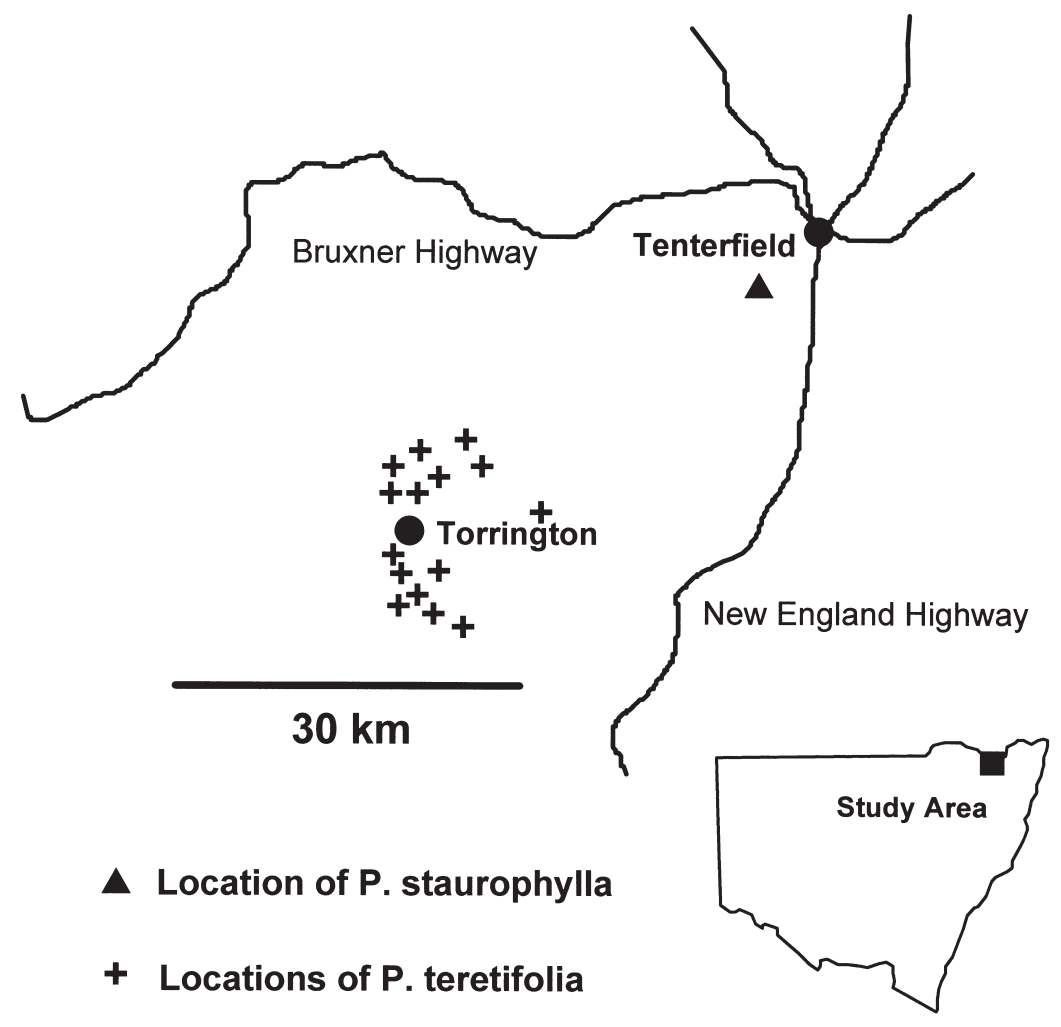

Fig. 3. Distribution map of Prostanthera staurophylla $(\boldsymbol{\Delta})$ and P. teretifolia (十), Northern Tablelands region of New South Wales, Australia

Table 1. Diagnostic characters separating Prostanthera staurophylla from P. teretifolia.

\section{Feature}

Leaves dimorphic

Adult lamina margin

Adult lamina length

Lamina adaxially densely glandular

Adult lamina non-glandular indumentum

Adult lamina abaxial surface visibility

Adult lamina lobes

Leaf colour

Stems branching

Corolla inner surface markings

Corolla length

Anther appendage

\section{P. staurophylla}

No

Recurved

2-9 mm

No

Stiff \& scabrid

Visible

0 or $(2-) 3(-7)$

Lime- to dark green

Intricate \& very densely branched

Present

15-18 mm long

1-1.4 mm long, with

triangular trichomes

\section{P. teretifolia}

Yes

Revolute (lamina subterete)

5-15 mm

Yes

Weak \& crisped

Obscured

0 or 2-3

Grey-green

Loosely branched

Absent

8-9 mm long

Absent or minute 
Habitat: Prostanthera teretifolia is also a species endemic to granite outcrops. It is found in open and exposed situations within crevices in heathlands and shrublands from elevations of $800-1200 \mathrm{~m}$ above sea level (Fig. 3). It is commonly associated with Leucopogon neoanglicus F.Muell. ex Benth., Kunzea bracteolata Maiden \& Betche, Leptospermum novaeangliae Joy Thomps., Leucopogon melaleucoides A.Cunn. ex DC., Acacia viscidula Benth., Brachyloma saxicola J.T.Hunter and Micromyrtus sessilis J.W.Green.

Notes: the curled hairs of the branchlets are especially common at the nodes and in two narrow zones on the internodes, with each zone on opposite 'sides' of the branchlets, extending from the leaf axil region to the next more distal nodal region between the opposite leaf bases.

The lamina of the leaves is not truly terete, but rather, the strongly revolute margin obscures the abaxial lamina surface, including the mid-vein, such that the lamina appears subterete.

Conservation status: Prostanthera teretifolia is restricted to the Torrington area. However, it is very common within the granite landscapes and has been described as a dominant species epitomizing shrublands of granitic outcrop communities of the New England Batholith (Hunter \& Clarke 1998). Thousands of plants exist with many of these occurring within the Torrington State Conservation Area under the protection of the New South Wales National Parks Service. Currently the species is listed under the ROTAP (Briggs \& Leigh 1996) code of 2RC-. This schedule should be changed slightly based on current information as the conservation status is considered adequate (2RCa).

\section{Acknowledgments}

The authors wish to thank Alan Hill (Department of Environment \& Conservation (N.S.W.), Parks and Wildlife Division) for assistance in the field when the Prostanthera staurophylla population was re-discovered. Joy Everett (NSW) provided guidance in regard to the submission of this article. Katy Sommerville and Catherine Gallagher (both MEL) for kindly providing additional information on the type material of P. staurophylla as held at MEL. We are grateful to Peter Jobson (NSW) for his advice on hand-writing on various collections. We thank Lesley Elkan (NSW) for skillfully illustrating the two species.

\section{References}

Baillie JEM, Hilton-Taylor C and Stuart SN (eds) (2004) 2004 IUCN Red List of Threatened Species. A Global Species Assessment. (http://www.iucn.org/themes/ssc/red_list_2004/ GSA_book/Red_List_2004_book.pdf) (Downloaded 16 June 2005).

Briggs JD \& Leigh JH (1996) Rare or Threatened Australian Plants, revised edition. (CSIRO Publishing: Collingwood)

Conn BJ (1984) A Taxonomic Revision of Prostanthera Labill. Section Klanderia (F.v. Muell.) Benth. (Labiatae). Journal of the Adelaide Botanic Gardens 6(3): 207-356.

Conn BJ (1992) Prostanthera. Pp. 646-662 in Harden GJ (ed.) Flora of New South Wales, vol. 3. (New South Wales University Press: Sydney) 
Conn BJ (1995) Description of inflorescence axes in the genus Logania R.Br. (Loganiaceae). Kew Bulletin 50: 777-783.

EPBC (1999) Environment Protection and Biodiversity Conservation Act 1999. (http://www. deh.gov.au/epbc/index.html)

Greuter W, NcNeill J, Barrie FR, Burdet H-M, Demoulin V, Filgueiras TS, Nicholson DH, Silva PC, Skog JE, Trehane P, Turland NJ \& Hawksworth DL (2000) International Code of Botanical Nomenclature (St Louis Code). Regnum Vegetabile 138. (Koeltz Scientific Books: Königstein)

Hunter JT (1997) Acacia williamsiana (Fabaceae: Juliflorae): A new granitic outcrop species from northern New South Wales. Journal of the Royal Society of Western Australia 80: 235-237.

Hunter JT (1998) Two new rare species of Homoranthus (Myrtaceae: Chamelaucieae) from the Northern Tablelands of New South Wales. Telopea 8: 35-40.

Hunter JT (2003) Persistence on inselbergs: the role of obligate seeders and resprouters. Journal of Biogeography 30: 497-510.

Hunter JT \& Clarke PJ (1998) The vegetation of granitic outcrop communities on the New England Batholith of eastern Australia. Cunninghamia 5: 547-618.

Hunter JT \& Copeland L (2001) Homoranthus binghiensis (Myrtaceae) a new species from the North Western Slopes of New South Wales. Telopea 9: 431-433.

Hunter JT, Quinn FC \& Bruhl JJ (1996) Micromyrtus grandis (Myrtaceae) a new species from New South Wales. Telopea 7: 77-81.

Maiden H \& Betche E (1908) Labiatae. Prostanthera teretifolia, n. sp. Proceedings of the Linnaean Society of New South Wales 33: 313 \& 314.

Mueller F. von (1875) Labiatae. Prostanthera staurophylla. Fragmenta Phytographiae Australiae 9: $73 \& 74$.

Orchard AE (1999) A History of Systematic Botany in Australia. Pp 11-105 in Orchard AE \& Thompson HS (eds) Flora of Australia, vol. 1, $2^{\text {nd }}$ edition (ABRS/CSIRO Australia: Melbourne)

TSC (1995) Threatened Speci es Conservation Act 1995 No 101 in 'In Force Legislation'. (http:// www.legislation.nsw.gov.au/maintop/search/inforce)

TSC (2002) Threatened Species Conservation Amendment Act 1995 No 78 in 'In Force Legislation' (http://www.legislation.nsw.gov.au/maintop/search/inforce)

TSC (2004) Threatened Species Conservation Amendment Act 1995 No 88 in 'In Force Legislation'. (http://www.legislation.nsw.gov.au/maintop/search/inforce)

Manuscript Received 22 June 2005, accepted 24 November 2005 